SPECIAL REPORT

\title{
Dolly: a decade on
}

Ten years ago, the birth of Dolly the sheep sparked a media frenzy and a prolonged ethical debate. Today, the arguments have switched focus to stem cells, and the research itself is beginning to change tack.

\section{$1 / S$} cientists clone adult sheep — triumph of UK raises alarm over human use," ran the first headline announcing the cloning of an adult mammal ten years ago this week. Ian Wilmut at the Roslin Institute near Edinburgh and his colleagues at PPL Therapeutics in East Lothian reported on 27 February 1997 that they had produced a lamb named Dolly, born the previous July, that was the first mammalian clone created using the genetic material from an adult cell ${ }^{1}$.

As soon as the story hit the front page (the news was broken by a British Sunday newspaper four days ahead of Nature's publication), a public and media maelstrom ensued.

"The first press calls came from New Zealand," recalls Sue Charles of Northbank Communications in London, who was handling publicity for Roslin and PPL at the time. "They worked their way through Australia, Asia and Europe." Later in the day, calls began coming in from the United States, with interest ranging from the science involved to politics and religion. "We even had a US chat show that wanted Dolly on," says Charles. "They offered to fly her over." She remembers that her team, together with Wilmut and his colleagues, took around 2,000 calls from journalists in two weeks.

But Dolly wasn't popular with everyone. Pundits warned of a future in which armies of human clones would be created by the evil and egotistical. Conservatives predicted the demise of the nuclear family. Activists cautioned that fertility doctors would perfect the technique and get rich making clones for the infertile, the narcissistic and the eccentric. US President Bill Clinton announced that the feat "raises serious ethical questions" and commanded his bioethics advisers to report to him in 90 days on measures he should take to prevent its abuse.

Ten years later, the ethical debate launched by Dolly, and encouraged by science-fiction stories, has changed. It has been supplanted by one that is more complex, more rooted in reality and far more relevant to the research that scientists want to do.

"What didn't happen was the birth of a [cloned] child or a widespread public demand for the use of cloning for reproduction," says Alta Charo, a professor of law and bioethics at the University of Wisconsin, Madison, who served as a bioethics adviser to Clinton. "What did happen was a complete shift in the ethical discussion from reproductive uses of cloning to research uses. And a merging of the cloning debate into the debate around embryonic stem-cell research - to the disadvantage of both fields because of the attendant confusion."

Back in early 1997, none of Wilmut and his colleagues, the referees who reviewed their paper, or the Nature editors who oversaw it, anticipated the huge public reaction to the cloning of Dolly. Scientists in the field saw her birth as an incremental advance - in large

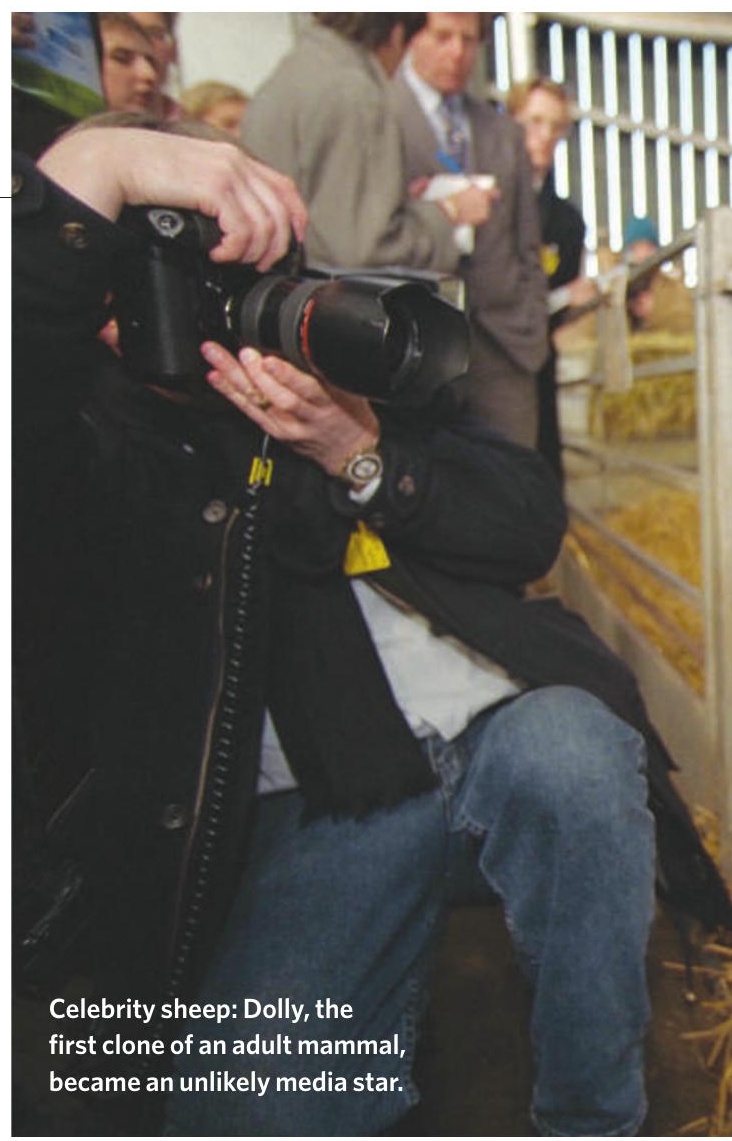

part because one year earlier, Nature had published a paper from Wilmut's group reporting the cloning of two lambs, Morag and Megan, using nuclei from embryonic cells ${ }^{2}$.

"I always maintained that Dolly was expected and Morag and Megan were truly surprising," says Davor Solter, director of the Max Planck Institute for Immunobiology in Freiburg, Germany. Solter wrote a News \& Views article in Nature about the paper on Morag and Megan, suggesting that it was time to start thinking about the implications and uses of cloning mammals from adult cells ${ }^{3}$.

Philip Campbell, Nature's editor-in-chief, also recalls that the media storm over Dolly took him by surprise. "Staff and referees were aware that this was the paper that in principle demonstrated how to clone mammals, including humans," he says. "But neither they nor I

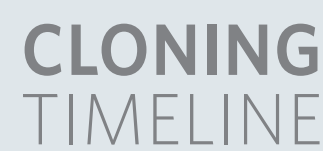

Robert Briggs and Thomas King in Philadelphia, Pennsylvania, describe how they cloned frogs (Rana pipiens) by replacing the nuclei of eggs with cells from tadpoles and adult intestinal epithelium. A similar experiment was first proposed by Hans Spemann at the University of Freiberg, Germany, in 1938.

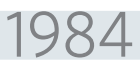

1996
Chinese researchers clone a fish

- the crucian carp (Carassius carassius) - from cultured kidney cells.
Researchers at the Roslin Institute in Scotland clone two lambs - Megan and Morag - from embryonic cells. This was a crucial step towards cloning an

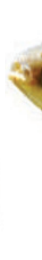

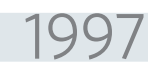

Roslin researchers

announce the birth of Dolly the sheep, the first mammal to be cloned from an adult cell, igniting public debate about the prospects for cloning humans.

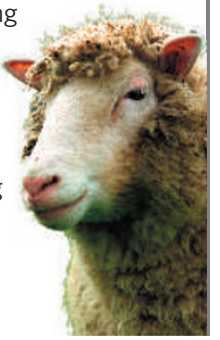



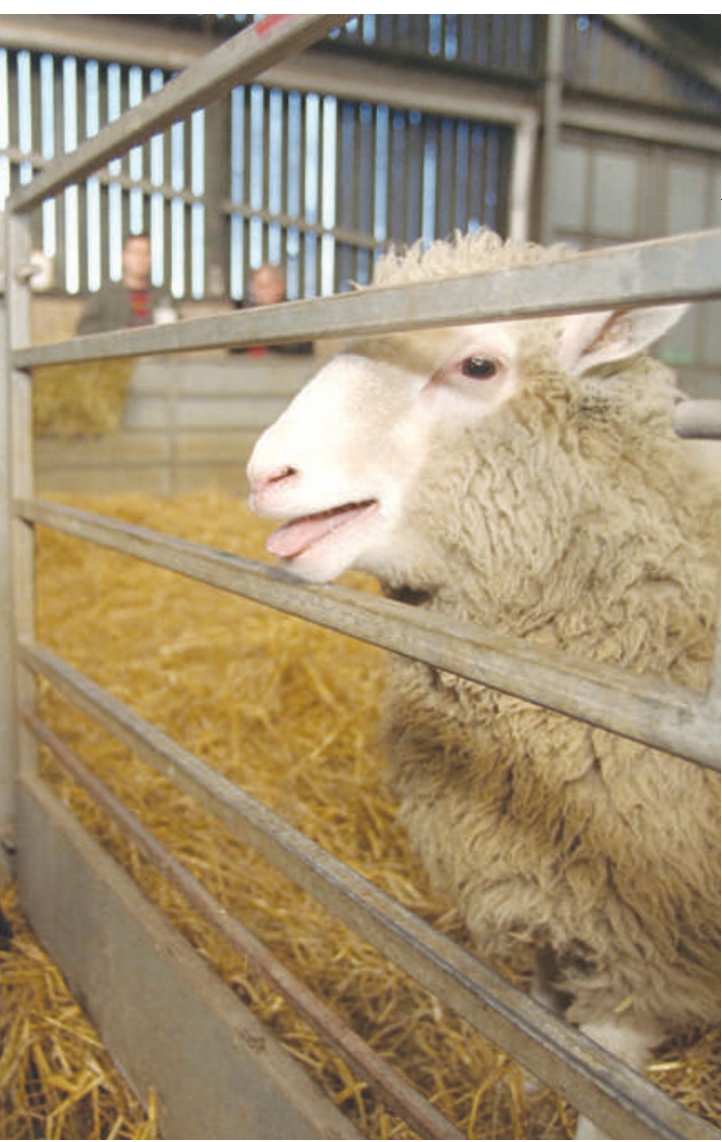

anticipated the furore. We were very focused on just how much of an advance it represented on Morag and Megan a year earlier."

But what to scientists was one small step, built on work dating back decades, was to the public the herald of a brave - and unwelcome - new world in which human clones would become as common as test-tube babies.

The claims that soon followed (of intentions to clone babies, or of having accomplished the deed) from sources including Chicago physicist Richard Seed, Italian embryologist Severino Antinori and the Raelian cult, which believes that the human race was cloned from aliens, only fanned the flames of the public imagination. At the outset, "kooks, cultists and conmen made all the news about cloning", recalls Arthur Caplan, director of the Center for Bioethics at the University of Pennsylvania in
Philadelphia. "This is one of those areas where just trying to rein in nutty behaviour became a full-time job."

But as the decade passed and a menagerie of other mammals was cloned (see 'Cloning timeline'), no cloned human babies appeared. What did occur, and what moved the ethical debate in an unforeseen direction, was the isolation of human embryonic stem-cell lines by James Thomson and his colleagues at the University of Wisconsin, Madison ${ }^{4}$.

With that achievement, it became clear that broad research avenues could be opened up by cloning human embryos to extract stem cells from them. These could then be used as disease models and drug targets, or to develop therapies involving tissue transplantation.

But as quickly as scientists recognized the potential of such opportunities, political and ethical opponents seized on the notion that allowing cloning in research would only ensure that it would one day be used for reproductive purposes. What's more, they argued, research cloning was a fundamental assault on human dignity, because it creates, manipulates and destroys human embryos for scientific ends.

"What really took place is that the stem-cell debate replaced the cloning debate," says Caplan. "Because there was - and is - a tremendous interest in trying to clone embryos, not people."

The South Korean scandal of Seoul National University's Woo Suk Hwang, whose claims to have derived stem-cell lines from cloned human embryos were proved to be fraudulent in 2006, generated plenty of bad press for the field. But there are signs that the new debate is taking a different course from that on reproductive cloning because of the potential of stem-cell research to improve human health.

In the United States, for example, opposition to cloning babies has remained firm through a decade of polling, at about $90 \%$, but polls in recent years have shown that $60-70 \%$ of the public supports research using stem cells obtained from discarded embryos in fertility clinics.

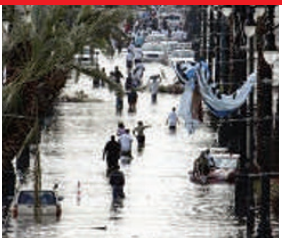

BLOGS TO THE RESCUE!

Proposal calls for web community to help professionals in disaster relief.

www.nature.com/news
"As people learn about the possibilities for new approaches to disease, they see the embryonic stem-cell issue in a different framework," says Jonathan Moreno, a bioethicist at the University of Pennsylvania, who co-chaired a committee that crafted 2005 research guidelines for the US National Academies. "They see it as medical research that could help them or their families"

The notion of cloning embryos to be a source of stem cells - as opposed to using embryos left over from fertility treatment that are slated for destruction anyway - is much more controversial. It remains a touchy political issue in many countries, including the United States, and is approached gingerly by public and private funders alike.

In the near term, "I rather doubt that we will see very much [cloning] in the context of embryonic stem-cell research in the United States", says Moreno. But he thinks advances are likely to come in countries where the work is seen as more acceptable, such as Britain, where groups led by Wilmut at the University of Edinburgh and Alison Murdoch at the International Centre for Life in Newcastle upon Tyne have been given permission to pursue it. (Murdoch's group has already cloned at least one human embryo, but has had no luck extracting stem-cell lines.)

As embryonic stem-cell research allows the genetic contributions to complex disease to be teased out, Charo believes that the ethical debate will shift again. Rather than focusing on the moral implications of cloning itself, she says, questions of an individual's responsibility for their known predisposition to disease will come to the fore: "If we move towards genetics research, we will have a new set of issues that Time and Newsweek can put on their covers." Meredith Wadman
Wilmut, I. et al. Nature $\mathbf{3 8 5}, \mathbf{8 1 0 - 8 1 3 ~ ( 1 9 9 7 ) ~}$
2. Campbell, K. H. S. et al. Nature 380, 64-66 (1996).
3. Solter, D. Nature 380, 24-25 (1996).
4. Thomson, J. A. et al. Science 282, 1145-1147 (1998).

See page 802 and Editorial, page 795.

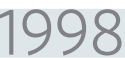

Scientists at the

University of Hawaii reveal the cloning of three generations of mice from the nuclei of adult cells, suggesting the technique could work on other

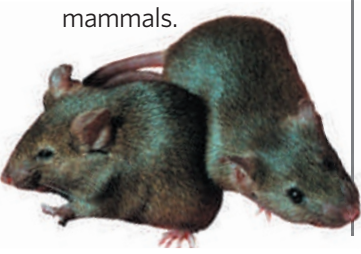

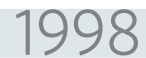

Japanese researchers report cloning eight calves using adult cells from slaughterhouse entrails, raising the possibility that animals could be cloned for the quality of their meat.

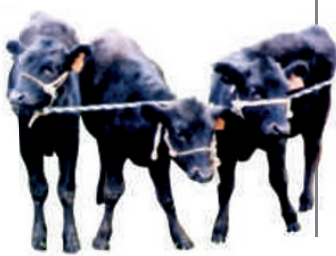

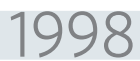

Scientists in New Zealand announce Elsie, a clone created from an adult cell from the last surviving Enderby Island cow (Bos gaurus). Attempts to clone endangered species have met with criticism that the technique will do little good without concurrent habitat preservation.

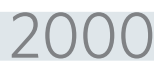

PPL Therapeutics in Scotland unveils a litter of five cloned piglets. The firm says that genetically engineered cloned pigs could one day provide a source of organ transplants for humans.

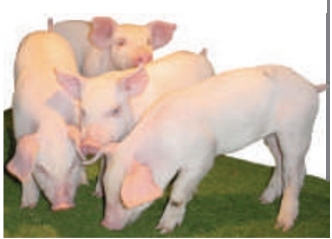

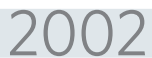

The first cloned cat (Felis domesticus), named cc for 'copycat', is announced by Texas A\&M researchers. Cc's coat pattern is not the same as her genetic donor's, showing the impact on development of nongenetic effects. 